\title{
Totally Laparoscopic Strategies for the Management of Colorectal Cancer with Synchronous Liver Metastasis
}

\author{
AMR F. EL-ALFY, M.Sc.; ADEL DENEWER, M.D., Ph.D.; NAZEM SHAMS, M.D., Ph.D.; \\ WALEED EL-NAHAS, M.D., Ph.D. and OMAR FAROUK, M.D., Ph.D.
}

The Department of Surgery, Surgical Oncology Unit, Oncology Center, Mansoura University (OCMU)

\begin{abstract}
Background: The purpose of this study is to compare the laparoscopic techniques for the management of colorectal cancer with synchronous liver metastases: tion.

Simultaneous laparoscopic liver and colon cancer resec-

Simultaneous colon resection and Radiofrequency Ablation (RFA) of liver metastases.

Methods: Convenient sample of about 30 patients expected to attend the Oncology Center, Mansoura University (OCMU) Gastro-Enterology Center (GEC) during study period of 3 years (2014-2017) with adenocarcinoma of the colon and rectum with Synchronous Colorectal Liver Metastases (SCRLM) will be considered.

Results: Mean operative time was 205 minutes for LLR, in comparison with the resection group, mean operative time for RFA was 185 minutes. Though shorter in time, this did not appear to be statistically significant ( $p$-value $=4.41)$. Mean blood loss for the resection group was $350 \mathrm{ml}$, and mean blood transfusion was $0.89 \mathrm{~L}$. On the other hand, mean blood loss for the RFA group was $90 \mathrm{ml}$ and mean blood transfusion was $0.76 \mathrm{~L}$. This difference between the two groups appeared to be statistically different ( $p$-value $=0.01)$. For the LLA group mean hospital stay 8.4 days and mean recovery time per case was 4.1 days. This was a bit shorter for the RFA group were mean hospital was 8.3 days while mean recovery time per case was 3.6 days. Although shorter, this difference appear to be insignificant statistically. $(p$-value $=0.95 / p$-value $=0.79$ respectively).
\end{abstract}

Conclusions: Treatment of hepatic metastasis especially in colorectal hepatic lesion could prolong survival in selected cases, all the results of the systemic reviews and meta-analysis suggested an inferior outcome of non resectional treatment compared to hepatic resection.

Minimal invasive approach for treatment of CRLM offers more advantages such as early recovery, less pain, better cosmosis, less blood loss, and reduced morbidity and mortality with equal oncological outcome compared to classic open surgery.

Correspondence to: Dr. Amr F. El-Alfy, E-Mail: dramrelalfy@mans.edu.eg
Key Words: CRLM - RFA - Laparoscopic liver resection Laparoscopic colorectal surgery.

\section{Introduction}

THE introduction of laparoscopy in surgery had a great impact on outcomes, laparoscopy is commonly used now in gastrointestinal cancer surgery and emergency surgical procedures. Colorectal Cancer (CRC) is the $3 \mathrm{rd}$ commonest cancer and the 4th leading cause of cancer deaths in the world. Approximately $25 \%-30 \%$ of CRC patients have concurrent liver metastasis on presentation. Liver is the most common site of hematogenous dissemination [1]

Laparoscopic colorectal surgery has become popular in recent years because of its absolute advantage of allowing fast return of bowel motion and a shorter hospital stay. Recently, laparoscopic synchronous resections of primary colorectal tumor and liver metastasis have been reported [2] .

The risk of bleeding is an important concern when conducting hepatic resection on patients who have received chemotherapy treating their primary cancer and the location of liver metastasis can be a challenge in laparoscopic liver resection [3] .

Both colorectal resection and hepatic resection are complicated operations. Whether combining these two complicated procedures in one laparoscopic surgery will do patients more harm or good is in hot debate. However, synchronous resections of primary colorectal tumor and liver metastasis by laparoscopy are not only feasible but also safe. So, this approach is an alternative to open resection in one or separate operations for selected patients. Evidence has shown that resection of solitary metastatic tumors of CRC can have a favorable outcome [4]. 
Since open resection of primary CRC and liver metastasis in one operation results in an equally good short-term outcome when compared with that done in separate operations, laparoscopic resection of the same in one single operation seems to be a favorable option. Recent evidence has shown that this approach is a safe alternative with a shorter hospital stay [5]

Patients with Colorectal Liver Metastasis (CRLM) should receive definitive treatment as they do not survive 5 years without treatment. Patients with colorectal liver metastasis have been classically treated with loco-regional therapy or systemic therapy, aiming for palliation [6]

However, in selected patients, treatment of CRLM offers a survival benefit more than a palliative benefit. Liver resection is the cornerstone of curative treatment for CRLM as it offers the best survival advantage. Liver resection is superior in treatment of CRLM with survival benefit of 27 $39 \%[7]$.

\section{Patients and Methods}

Convenient sample of about 30 patients expected to attend the Oncology Center, Mansoura University (OCMU) and Gastro-Enterology Center (GEC) during study period of 3 years (2014-2017) with colonic or rectal carcinoma with Synchronous Colorectal Liver Metastases (SCRLM) will be considered. Our cases were discussed by a multidisciplinary team composed of surgeons, oncologists, pathologists, and radiologists. In cases with resect-able disease and a synchronous resection was considered, and when not applicable, RFA was considered as an alternate option.

Inclusion criteria: Were adult patients, pathologically confirmed colorectal cancer with SCRLM, amenable for elective surgery, resectable CRLM. (defined as CRLM for which an experienced hepatobiliary surgeon judges that complete tumor resection is possible, obtaining negative resection margins (R0) and preserving adequate liver reserve). Exclusion criteria included those undergoing emergency surgery, positive lymph nodes at the hepatic hilum and past or present extrahepatic metastases. Written consent was taken from all patients and this clinical trial was approved by the 'Institutional Review Board' of Faculty of Medicine.

\section{Pre-operative preparations:}

All patients were be subjected to the following thorough history taking, general examination and abdominal examination. Evaluating all patients for anesthetic fitness was done after consulting the anesthesia team. Laboratory investigations, radiological investigations (triphasic CT and abdominal US) and pathological investigation were done.

\section{Operative technique:}

The operator stands on the right side of the patient for left sided lesions while stands between the patient's legs for right sided and central lesions.

Ports are inserted, usually four to six ports are used which include (1) A peri-umbilical 10-mm optical port; (2) A 12-mm port for laparoscopic USG usually $10 \mathrm{~cm}$ above and to the right of optical port, which also serves as a port for insertion of stapling devices; and (3) Three to four working ports around the optical port. Carbon dioxide pneumo-peritoneum was created with pressure 12$14 \mathrm{mmHg}$. Then thorough abdominal evaluation was conducted to detect any other abdominal metastasis, followed by Intra-Operative Ultrasonography (IOUS). An IOUS is routinely performed to detect site of the lesion, relation to vessels, omit multiplicity of tumors, and to guide the resection planes. The resection margin was identified on the liver surface using electrocautery. Stay stitches are placed around to allow traction and counter traction during parenchymal transection.

The hepatic resection was achieved with the help of multiple devices, including Harmonic scalpel and Argon Laser for superficial liver parenchyma and Cavitron Ultrasonic Surgical Aspirator (CUSA), LigaSure (ValleyLab) and bipolar forceps for deeper liver parenchyma.

The resection of colonic tumor was conducted according to the accepted principles of laparoscopic colorectal surgery: Namely, medial to lateral approach, high ligation of the vessels, no-touch technique with full mobilization of splenic flexure, and Total Meso-rectal Excision (TME). Non anatomical resection of the hepatic mets with safety margin $1 \mathrm{~cm}$ was conducted, two cases underwent laparoscopic left lateral hepatectomy.

For laparoscopic RFA, the probe was usually inserted through the epigastric port. An endoretractor was used to expose the tumor and to protect against visceral injury in the event that the tumor is located on the inferior surface, which is hidden by adjacent viscera.

\section{Post-operative care:}

Patients after surgery were transferred either to the ICU, HDU or the normal ward according to their vital signs \pm pre-existing comorbidities for follow-up and close monitoring of their vital signs, drains and fluid balance. Unless contra-indicated, 
a combination of local anesthetic (Bupivacaine $0.125 \%$ ) and an opiate or opioid-like drugs (fentanyl, meperidine, pethidine) were administered in the epidurals, IV or as dermal patches (Duragesic ${ }^{\circledR}$ patch) when needed in the PO period. Patients unfit for opiate therapy received analgesic doses of NSAIDs at timed intervals only.

Patients were allowed to get out of bed on the night of surgery as long as tolerable and in the next morning following the day of surgery (POD 1) except non-compliant patients with bad general condition. Enteral nutrition was initiated once the patients passed motion or flatus and had good intestinal sounds but not before 3 days from the day of surgery. Full enteral nutrition was the "key determinant" to successful hospital leave.

Abdominal drains were removed after sustaining full enteral nutrition which is usually before patient's discharge. Subcutaneous drains were removed when they discharged less than 20cc/day and were left for pus drainage from the wound when infection occurred. After maintaining full oral nutrition and after removal of all drains patients were fit to be discharged. Follow up by liver function tests, serum CEA, and triphasic CT every 3 months for 2 years.

\section{Statistical analysis:}

Analysis of data was performed using Statistical Package for Scientific Studies (SPSS) v.22 for Windows 7. Numerical data was expressed as means \pm Standard Deviation (SD) and comparisons between groups were done using $\chi$ test and Fisher's exact test while for categorical data, independent sample $t$-test was used. $p$-value $<0.05$ was considered significant.

\section{Results}

During the study period 30 cases diagnosed with CRLM underwent different laparoscopic liver procedures at the Surgical Oncology Unit Mansoura Oncology Center and Gastro Enterology Center, 15 cases underwent Laparoscopic Liver Resection (LLR) and 15 cases underwent laparoscopic RFA.

Age: Mean age of the patients who underwent LLR was 56.39 years (40-73), while mean age of the patients who underwent RFA was 56.75. There was no statistical difference between both groups regarding the age $(p$-value $=0.58)$.

Sex: As regard the LLR group male to female patient ratio was (6/9), while for the RFA group 2 patients only were female while the others were males (13/2).

\section{Multifocality:}

Single hepatic focal lesion was present in 22 patients $(73.3 \%)$, while 8 patients had multiple lesions (26.6\%), 6 cases of them had 3 hepatic focal lesion and the remaining 2 cases had only 2 hepatic focal lesion.

\section{Type of resection:}

Minor resections were done in 13 patients $(86.6 \%)$, while major resection were done in 2 patients $(13.3 \%)$ in the form of left lateral hepatectomy.

\section{Conversion into open surgery:}

Open conversion was necessary in 5 cases (16.6\%) due to bleeding in 2 cases $(6.6 \%)$, massive adhesions in 1 cases $(3.3 \%)$, difficult accessibility of lesions in 2 cases $(6.6 \%)$.

\section{Operative time:}

Mean operative time was 205 minutes for LLR, in comparison with the resection group, mean operative time for RFA was 185 minutes. Though shorter in time, this did not appear to be statistically significant $(p$-value $=4.41)$.

\section{Blood loss and blood transfusion:}

Mean blood loss for the resection group was $350 \mathrm{ml}$, and mean blood transfusion was $0.89 \mathrm{~L}$. On the other hand, mean blood loss for the RFA group was $90 \mathrm{ml}$ and mean blood transfusion was $0.76 \mathrm{~L}$. This difference between the two groups appeared to be statistically different $(p$-value $=0.01)$.

\section{Hospital stay and recovery:}

Both items were accurately measured and compared statically between both groups. For the LLA group mean hospital stay 8.4 days and mean recovery time per case was 4.1 days.

This was a bit shorter for the RFA group were mean hospital was 8.3 days while mean recovery time per case was 3.6 days. Although shorter, this difference appear to be insignificant statistically. $(p$-value $=0.95 / p$-value $=0.79$ respectively $)$.

\section{Discussion}

Laparoscopy has many advantages in colorectal surgery such as rapid return of bowel motility and short hospital stay. Recently, synchronous laparoscopic resections of colonic tumor and CRLM have been reported [8].

The international consensus conference on laparoscopic liver surgery was held in Morioka, Iwate Prefecture, Japan, in 2014. They reported 
that a global spread of LLR has occurred. The majority of data arise from minor resections but the proportion of major resections is increasing. They did not report the indications for LLR and recommended that major LRs should be reserved to experienced surgeons [9].

Dealing with CLRM has many points to be discussed, for example should we start with neoadjuvant treatment or with upfront surgery, surgery is either open or laparoscopic approach, in surgery should we proceed for simultaneous resection of both colonic tumor and CRLM or staged resection, as regard CRLM which model of treatment do we prefer either surgical resection or ablative therapy.

They identified 5 factors including nodepositive disease, disease-free survival from primary to metastatic disease, number of CRLM $>1$, largest CRLM $>5 \mathrm{~cm}$ and CEA antigen $>200 \mathrm{ng} / \mathrm{mL}$ with each factor given one point. The combined score was found to be greatly predictive of the outcome. This score only was validated for patients with upfront surgery and doesn't include patients who receive neoadjuvant therapy; so its validity in modern treatment is limited.

\section{Type of resection:}

In our study minor wedge resections were done in 18 patients $(83.2 \%)$, while major resection were done in 2 patients $(16.8 \%)$ in the form of left lateral hepatectomy.

Our target is the achievement of R0 resection with safeguarding of as much healthy hepatic tissue as possible so, it does not matter which type of resection would be used either anatomical or nonanatomical, provided that negative histological margins could be attained [10]

Regardless of the length of resection margin, achieving a negative margin is the most significant predictor of overall survival, there is no role of incomplete resection [11].

Policies to expand hepatic volume like portal vein embolization or staged resection were not applied in our work because we always planned for non anatomical resections for liver metastasis that seldom affects post-operative liver status.

\section{Conversion to open approach:}

In laparoscopic liver resection for treatment of CRLM conversion rate is low fluctuating from 1$12 \%$ in different studies and decrease with improving the learning curve [12].
In our work open conversion was necessary in 5 cases $(16.6 \%)$ due to bleeding in 2 cases $(6.6 \%)$, massive adhesions in 1 cases $(3.3 \%)$, difficult accessibility of lesions in 2 cases $(6.6 \%)$.

This appeared to be a bit larger than the average in the published studies due to our small experience in laparoscopic liver resection and deficient instrumentation in some cases. The availability of flexible laparoscope and navigation techniques may help us in reducing rate of conversions especially in difficult accessed sites in addition to increased learning curve of our team.

\section{Operative time:}

Operative time is an important item to be discussed, as it has a great variation between literatures. Some authors had suggested that laparoscopic liver resection is associated with shorter operative duration, whereas others suggested that LLR had a meaningfully more average operative duration. This could be explained by (1) The type of resection major/minor and (2) Surgeons experience.

In our study operative time is considered an important item for comparison between the both techniques in management of CRLM.

Mean operative time was 205 minutes for LLR, in comparison with the resection group, mean operative time for RFA was 185 minutes. Though shorter in time, this did not appear to be statistically significant $(p$-value $=4.41)$.

In a study comparing both laparoscopic resection and laparoscopic radiofrequency in treatment of CRLM, the median operative time for the combined resections was 530 (range, 360-980) min. while the median operative time for synchronous colon resection with liver RFA was 310 (range, 240-425) min [13] .

\section{Bleeding and blood transfusion:}

In another study comparing both laparoscopic resection and laparoscopic radiofrequency in treatment of CRLM, the median blood loss for LLR was 175 (range, 30-1,000) $\mathrm{ml}$ and the median blood loss for RFA was 22 (range, 10-150) $\mathrm{ml}$ [14].

In our work, bleeding occurred in $12 \%$ of the patients which appears a bit higher than average in the published literature. This may be due to our small experience in the field of laparoscopic surgery, though the proper choice of patients and good preparation with the fine intra-operative dissection with the use of sealing instruments made this difference small. 
Mean blood loss for the resection group was $350 \mathrm{ml}$, and mean blood transfusion was $0.89 \mathrm{~L}$. On the other hand, mean blood loss for the RFA group was $90 \mathrm{ml}$, and mean blood transfusion was $0.76 \mathrm{~L}$. This difference between the two groups appeared to be statistically different $(p$-value $=0.01)$.

\section{Hospital stay and recovery:}

Recovery after intervention for colorectal liver metastasis and hence, the duration of hospital stay has an important impact on both physical and psychological status of the patient and also, has an important financial impact.

Both items were accurately measured and compared statistically between both groups. For the LLA group mean hospital stay 8.4 days and mean recovery time per case was 4.1 days. This was a bit shorter for the RFA group were mean hospital was 8.3 days while mean recovery time per case was 3.6 days. Although shorter, this difference appears statistically insignificant. Although shorter, this difference appear to be insignificant statistically. $(p$-value $=0.95 / p$-value $=0.79$ respectively $)$.

\section{Conclusion:}

Treatment of hepatic metastasis especially in colorectal hepatic lesion could prolong survival in selected cases, all the results of the systemic reviews and meta-analysis suggested an inferior outcome of non resectional treatment compared to hepatic resection. Minimal invasive approach for treatment of CRLM offers more advantages such as early recovery, less pain, better cosmosis, less blood loss, and reduced morbidity and mortality with equal oncological outcome compared to classic open surgery.

\section{References}

1- ADAM R.: Resection of non resectable liver metastases after chemotherapy: Prognostic factors and longterm results. J. Clin. Oncol., 22 (Suppl. 14): 3550, 2014.

2- BRETAGNOL F., HATWELL C., FARGES O., ALVES A. and PANIS Y.: Benefit of laparoscopy for rectal resection in patients operated simultaneously for synchronous liver metastases: Preliminary Experience Surgery, 144: p: 436-41, 2013.

3- GUMBS A.A. and GAYET B.: Totally laparoscopic central hepatectomy. J. Gastrointest. Surg., 12: 1153, 2013.
4- COOK A.D., SINGLE R. and M.C. CAHILL L.E.: Surgical resection of primary tumors in patients who present with stage IV colorectal cancer: An analysis of surveillance, epidemiology, and end results data. Ann. Surg. Oncol., 12: p. 637-45, 2013.

5- NGUYEN K.T., LAURENT A., DAGHER I., GELLER D.A., STEELI, THOMAS M.T. and MARVIN M.: Minimally invasive liver resection for metastatic colorectal cancer: A multi-institutional, international report of safety, feasibility, and early outcomes. Ann. Surg., 250: p. 842$8,2014$.

6- ABBAS S., LAM V. and HOLLAND M.: Ten-year survival after liver resection for colorectal metastases: Systematic review and meta-analysis. ISRN Oncol., doi: 10.5402/ 2011/763245, 2011.

7- KANAS G.P., TAYLOR A., PRIMROSE J.N., LANGEBERG W.J., KELSH M.A., MOWAT F.S., ALEXANDER D.D., CHOTI M.A. and POSTON G.: Survival after liver resection in metastatic colorectal cancer: Review and meta-analysis of prognostic factors. Clin. Epidemiol., 4: 283-301, 2012.

8- MORRIS E.J., FORMAN D., THOMAS J.D., QUIRKE P., TAYLOR E.F., FAIRLEY L., COTTIER B. and POSTON G.: Surgical management and outcomes of colorectal cancer liver metastases. Br. J. Surg.; 97: 1110-1118 [PMID: 20632280 Doi: 10.1002/bjs.7032], 2012.

9- WAKABAYASHI G., CHERQUI D., GELLER D.A., BUELL J., KANEKO H., HAN H.S., et al.: Recommendations for Laparoscopic Liver Resection. A Report From the Second International Consensus Conference Held in Morioka. Annals of Surgery, 261 (4): 619-29, 2015.

10- PAWLIK T.M., SCOGGINS C.R., ZORZI D., ABDALLA E.K., ANDRES A., ENG C., et al.: Effect of surgical margin status on survival and site of recurrence after hepatic resection for colorectal metastases. Ann. Surg., 241: 715-22, discussion 722-4, 2012.

11- HUH J.W., KOH Y.S., KIM H.R., CHO C.K. and KIM Y.J.: Comparison of laparoscopic and open colorectal resections for patients under-going simultaneous R0 resection for liver metastases. Surg. Endosc., 25 (1): 1938, 2011.

12- ABU HILAL M., UNDERWOOD T., ZUCCARO M., PRIMROSE J. and PEARCE N.: Short- and medium-term results of totally laparoscopic resection for colorectal liver metastases. Br. J. Surg., 97 (6): 927-33, 2010.

13- BALACHANDRAN V.P., ARORA A., GÖNEN M., et al.: A validated prognostic multigene expression assay for overall survival in resected colorectal cancer liver metastases. Clin. Cancer Res., 22: 2575-82, 2016.

14- FRANCESCO M., POLIGNANO, AARON J. QUYN, PANDANABOYANA SANJAY, NIKOLA A. HENDERSON and IAIN S. TAIT: "Totally laparoscopic strategies for the management of colorectal cancer with synchronous liver metastasis" Surg. Endosc., 26: 2571-8, 2012. 


\section{علاج سرطان القولون بالمنظار الجراحى مع وجود ثانويات في الكبد}

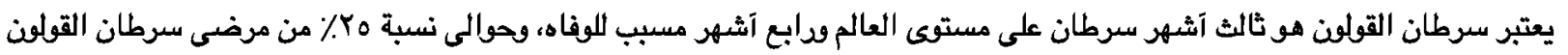

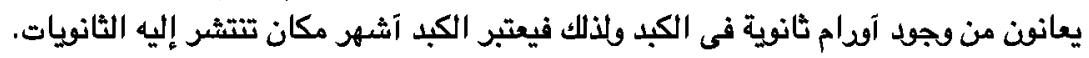

وقد آثبتت الدراسات الحديثة إن إستئصال ثانويات الكبد فى نفس وقت إستئمال ودم القولون يحمل آثار إيجابية كثيرة المريض، هذا

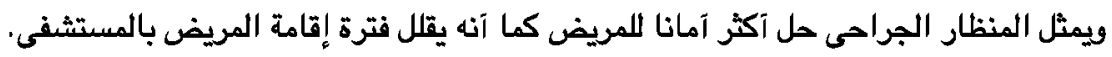
وبالإضافة إلى إستئصال ثانويات الكبد بالمنظار الجراحى فيوجد آيضا الكى بالتردد الحرارى وهى آيضا طريقة فعالة وقد آعطت نتائج

وقد إنتشرت عمليات إستئصال آورام القولون بالمنظار الجراحى فى الآونه الآخيرة إنتشارا واسعا لما تمثه من سرعة عودة المريض لحياته

يظل النزيف هو الخطر الآكبر في عمليات إستئهال ثانويات الكبد وخاصة المرضى الذين يخضيعون اللعلاج الكيماوى، ولذلك تطلب هذه العمليات إختيار دقيق المرضى التجنب حدوث الاكير فلك المضاعفات. طريقة البحث: يخضع المريض لفحوصات ما قبل العملية والتى تتضمن: 1- 1 - مصوة دم كاملة.

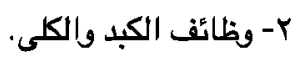

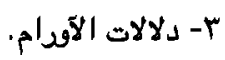
ع- المنظار الشرجى وآخذ العينة.

م- الآثبعة المقطعية.

ثم يخضع المريض لتحضير القولون فى صوده الحقنة الشرجية مع آخذ المضاد الصيوى لمدة يومين. ثم يخضع المريض العملية الجراحية والتى تتضمن عمل إستكثاف بالمنظار الجراحى وإستئصال ودم القولون مع إستئصال ثانويات الكبد

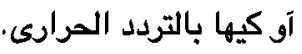
تجمع البيانات من المرضى وهى مدة الإقامة، إرتجاع الودم، وقت المملية وعدد آكياس الدم ثم تجرى الإحصاء لهذه البيانات.

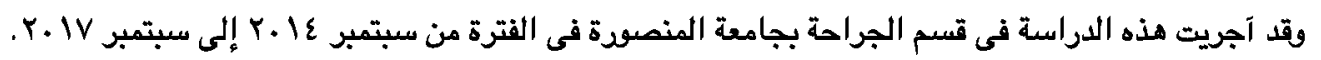

